\title{
Underground Diamond Mining at Ekati and Diavik Diamond Mines
}

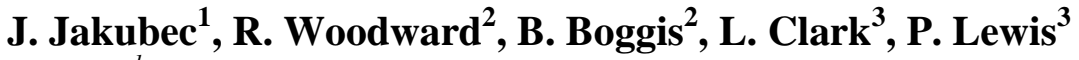 \\ ${ }^{1}$ SRK Consulting, Vancouver, Canada,jjakubec@srk.com \\ ${ }^{2}$ Dominion Diamond Corporation, Yellowknife,Canada, rick.woodward@ddcorp.ca \\ ${ }^{2}$ Dominion Diamond Corporation, Yellowknife,Canada, bill.boggis@ddcorp.ca \\ ${ }^{3}$ Rio Tinto - Diavik Diamond Mines, Yellowknife, Canda, lyndon.clark@riotinto.com \\ ${ }^{4}$ Rio Tinto - Diavik Diamond Mines, Yellowknife, Canda, philip.lewis2@riotinto.com
}

\section{Introduction}

Primary diamond deposits are being mined on an industrial scale only within the past 150 years, mainly as open pit mines. Underground mining of these deposits were implemented only within the second half of the $20^{\text {th }}$ century in South Africa. Over the past 50 years, a relatively large number of underground mining methods were tested, implemented, and evolved mainly in South African mines. In mid 1990s, Alrosa started the development of the first underground diamond mine in Russia, Internationalnaya. Since then, underground mining was implemented on several of their mines including Aikhal, Mir, and Udachny. China had also experimented with underground mining at Nhangma 701 Diamond Mine in the end of the nineties. Today, out of some 40 diamond mines mining kimberlite, approximately half are underground and another 20 have underground plans or the potential to mine underground.

\section{Canadian Underground Diamond Mines Overview}

The largest growth of diamond underground mining in the world was experienced in Canada. To date, underground mining was introduced on five kimberlite pipes and one kimberlite sill. Those are Panda, Koala, Koala North at Ekati Mine, A418, A514N, A514S at Diavik Mine and Snap Lake. Although in 2008 De Beers started underground mining on kimberlite sill at Snap Lake, the focus of this paper is to document experiences with underground mining of kimberlite pipes at Ekati and Diavik Mines see Figure 1.
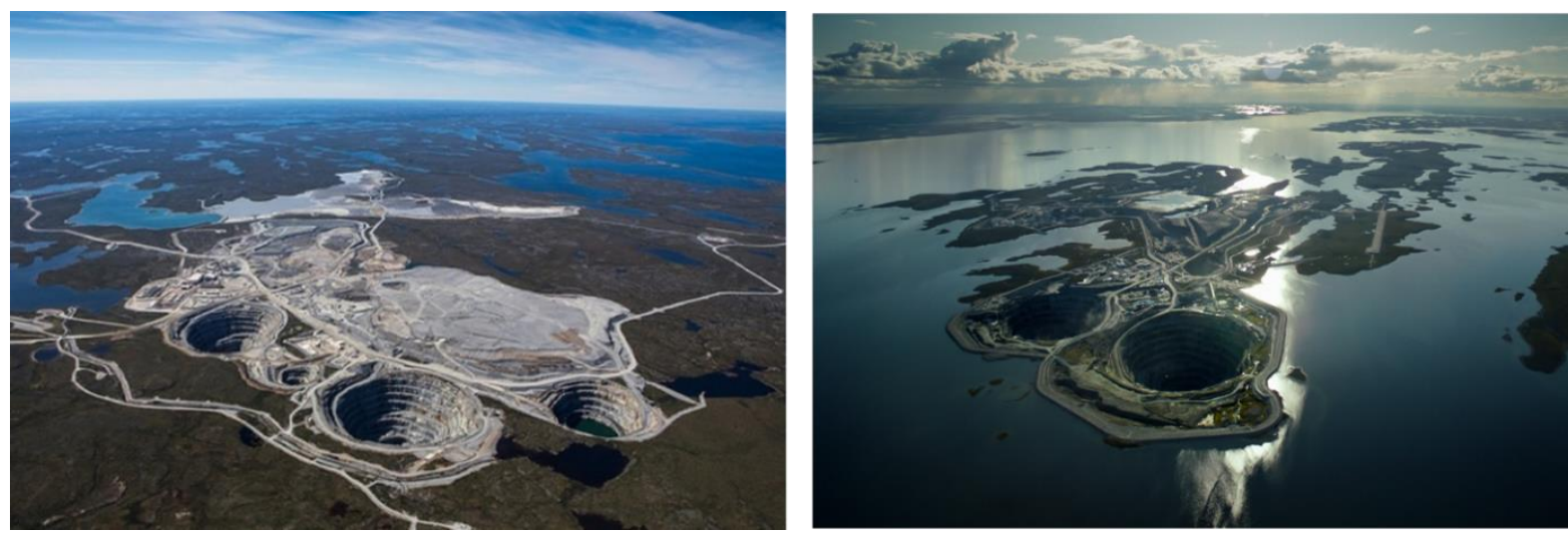

Figure 1: Ekati Mine left and Diavik Mine on the right.

Ekati Diamond Mine was the first diamond mine to be developed near Lac de Gras in the Northwest Territories of Canada and mining commenced as open pit at Panda pipe. Almost concurrently, planning was underway for underground mining at Panda and Koala pipes.

The Koala North pipe has been selected as a trial underground mine for the purposes of testing mining methods and to provide access to the lower elevations of the Panda and Koala pipes. The upper 40 meters of the Koala North pipe was mined in late 2000 as open pit which provided grade and geotechnical information and a prepared surface for the transition to underground mining. The trial mining decision was made primarily because of uncertainty in the several aspects of sub-level retreat (SLR) in the northern Arctic environment. In 2002, Koala North underground was formally opened 
and it becomes North America's first underground diamond mine. Koala North pipe has been successfully mined as mechanized open-benching down to 2115 level (+115 AMSL) and proved that SLR is technically feasible and economically viable mining method for exploiting kimberlite pipes in Arctic. Since then, Panda and Koala pipes were also mined as underground mines after open pits were completed and several other pipes are being investigated for underground mining. At Ekati, three principal underground mining methods were utilized including SLR, sub-level caving (SLC) and incline cave (IC) mining. Table 1 illustrates the production to date from Ekati underground and open pit mines.

\begin{tabular}{|l|l|c|l|l|}
\hline Mining Method & Pipe & Mining Method & $\begin{array}{c}\text { Production Rate } \\
\text { Mwmt/annum }\end{array}$ & $\begin{array}{c}\text { Tons Produced } \\
\text { Mdmt }\end{array}$ \\
\hline Open Pit & Panda & Open Pit & 2.8 & 14.2 \\
\hline & Koala & Open Pit & 3.5 & 9.4 \\
\hline & Beartooth & Open Pit & 0.4 & 1.8 \\
\hline & Misery & Open Pit & 1.4 & $\begin{array}{l}8.7 \text { (includes } \\
\text { inferred } \\
\text { satellites) }\end{array}$ \\
\hline & Fox & Open Pit & 3.1 & 24.3 \\
\hline & \multicolumn{5}{|l|}{} \\
\hline Underground & Panda & SLR & 1.1 & 4.7 \\
\hline & Koala & SLC, IC & 1.0 & $\begin{array}{l}8.2 \\
\text { IC Still operating }\end{array}$ \\
\hline & Koala North & SLR & 0.3 & 1.8 \\
\hline
\end{tabular}

Table 1: Ekati Underground and Open Pit Mines Production to Date

Diavik Diamond Mine started open pit production in 2003. By 2005, underground development had commenced with plans to mine the A154 and A418 pipes using backfill methods. As geotechnical knowledge was gained, the mining methods were re-evaluated and the sub-level retreat method was chosen for the A154S and A418 pipes, and blasthole stoping (BHS) with cemented rockfill was chosen for the A154N pipe. In 2012, the open pits reached their ultimate depths and Diavik became a fully underground operation. The current mine life is approximately 2024 and mining to date at Diavik is illustrated in Table 2.

\begin{tabular}{|l|l|l|l|c|}
\hline Mining Method & Pipe & $\begin{array}{l}\text { Mining } \\
\text { Method }\end{array}$ & \multicolumn{1}{c|}{$\begin{array}{c}\text { Production Rate } \\
\text { Mt/anum }\end{array}$} & $\begin{array}{c}\text { Tons Produced } \\
\text { t }\end{array}$ \\
\hline Open Pit (2003-2010) & $\begin{array}{l}\text { A154S } \\
\& \\
\text { A154N }\end{array}$ & Open Pit & 1.61 (avg) & 12.9 \\
\hline Open Pit (2008-2012) & A418 & Open Pit & $1.10($ avg) & 5.5 \\
\hline Underground (2010 start) & A154N & BHS & 0.57 (avg), 0.75 (current) & 4.0 \\
\hline Underground (2010 start) & A154S & SLR & 0.40 (avg), 0.49 (current) & 2.8 \\
\hline Underground (2011start) & A418 & SLR & 0.58 (avg), 1.10 (current) & 3.5 \\
\hline
\end{tabular}

Table 2: Diavik Underground and Open Pit Mines Production to Date

\section{Underground Mining Methods}

While blasthole stoping with cemented rockfill used at Diavik and SLC used at Ekati are a commonly used method in Canadian underground operations, sub-level retreat was newly introduced to Canada; hence, this paper will focus on SLR, mining method. The decision to select sub-level retreat was made as a result of technical, economical and safety risk consideration. Competent country rocks, favorable geometry, relatively competent kimberlite, and most importantly, the arctic context of the projects 
played an important role in the mining method selection process at both Ekati and Diavik Mines. The schematic section illustrating SLR method is shown in Figure 2.
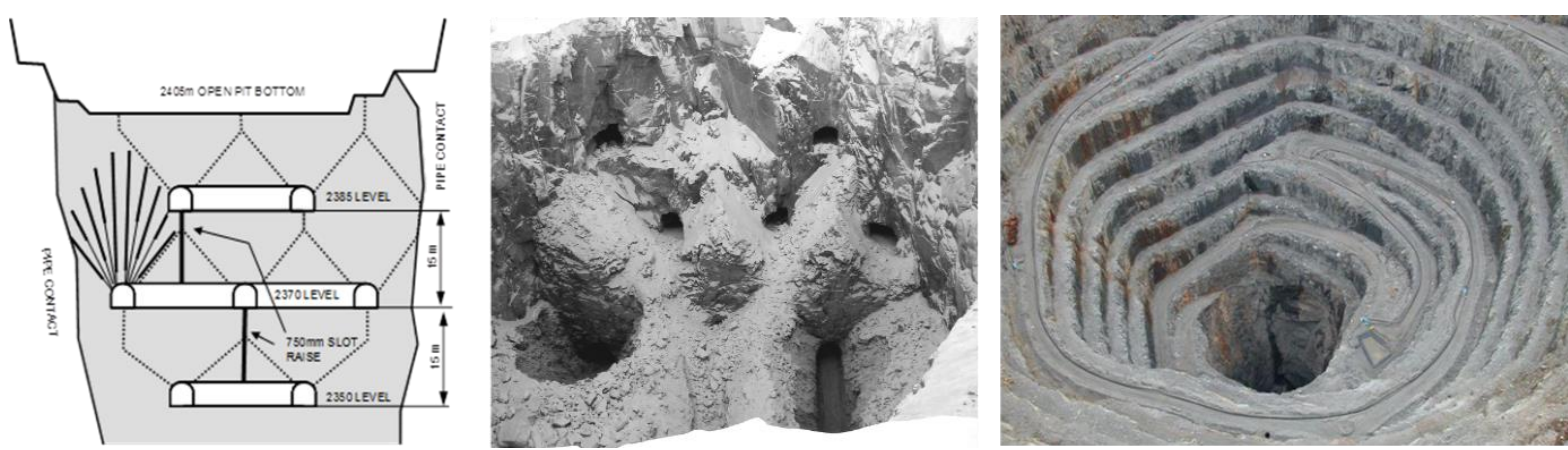

Figure 2: Schematic section through SLR mine (left) and view into Koala North (middle) and Panda (right) mines, both exploited by SLR.

Ekati mine successfully produced from Panda and Koala North pipes approximately 6.5 Mt of ore between 2002-2012 and Diavik produced approximately 6.3 Mt to date and by SLR.

\section{References}

Jakubec, J., Long, L., Nowicki, T., Dyck D., "Underground Geotechnical and Geological Investigation at Ekati Diamond Mine - Koala North Case Study", 8th International Kimberlite Conference, Victoria, 2002, Lithos, v. 76, iss. 1-4 [SPECIAL ISSUE], p. 337-345, 2004

Jakubec, J., Page C., Harvey, P., "Mining Method Selection for Diamond Mines - Challenges in the Arctic", MASSMIN 2004, Santiago, Chile, Aug. 2004

Jakubec, J., Long, L., "Open Benching at Ekati Mine - Koala North Case Study", MASSMIN 2004, Santiago, Chile, Aug. 2004 